\title{
Попова Л.В., Слинько А.Е. Социальная реклама как компонент формирования антитеррористических и антиэкстремистских ценностей в молодежной среде
}

В статье рассматривается проблема формирования антитеррористических и антиэкстремистских иенностей в молодежной среде. Делается акцент на применении социальной рекламы как компонента формирования антитеррористических и антиэкстремистских ченностей в молодежной среде.

Ключевые слова: антитеррористические и антиэкстремистские ченности, молодежь, социальная реклама.

Терроризм по своим масштабам и последствиям, разрушающей силе и жестокости превратился сегодня в одну из самых страшных проблем человечества. Как отмечает первый заместитель руководителя аппарата Национального антитеррористического комитета Е.П. Ильин, «Российская Федерация на протяжении последних 15 лет находится в состоянии постоянного противодействия террористическим угрозам. Первые годы XXI в. также отмечены крупными, тщательно подготовленными террористическими актами на территории нашей страны. Среди них особое место занимают подрывы пассажирских самолетов в Ростовской и Тульской областях, взрывы домов в Москве, Буйнакске и Волгодонске, захват театрального центра на Дубровке и школы в г. Беслане, нападения крупных бандформирований на города Назрань, Грозный, Нальчик, подрывы скорого поезда № 166 “Невский экспресс" и электропоезда “Кисловодск - Минводы”» [3].

Одной из главных задач борьбы с терроризмом является, наряду с методами силового воздействия непосредственно в ситуациях террористического акта, ликвидация террористической угрозы «в зачатке». В настоящее время ведутся поиски решения данной проблемы в рамках правовых, религиоведческих, философских, психологических, педагогических наук. Разрабатываются программы и лекционные курсы на базе ведущих вузов страны. Например, на базе факультета психологии Южного федерального университета в 2010 г. был разработан курс лекций для индивидуальной пропагандистской деятельности, материалы которого используются для работы, как среди руководителей региональных органов власти, органов местного самоуправления, так и в системе образования.

В настоящее время на уровне заявлений руководителей государства и силовых структур первостепенное значение придается вопросам силового воздействия на террористические группировки, ликвидации лидеров и членов террористических формирований. В то же время многие исследователи уже давно пришли к выводу о необходимости учета ценностного фактора при решении вопросов в сфере безопасности, в том числе и национальной безопасности. Так, мы полностью согласны с позицией В.Л. Манилова, который еще в середине 90-х гг. XX в. утверждал, что принципиально важно при формировании и проведении в жизнь 
политики и стратегии национальной безопасности приоритет отдавать не защите, а последовательной, твердой и эффективной реализации ценностей и интересов в обстановке различных опасностей и угроз [4]. Пристальное внимание при выработке ценностей необходимо уделять именно в работе с молодежью.

А.Н. Перенджиев в своей статье проводит анализ российских ценностей в области противодействия терроризму на основе документа «Стратегии национальной безопасности Российской федерации до 2020 года», в котором отмечается и признается все возрастающая роль ценностей в международных процессах [8]. «Между государствами обострились противоречия, связанные с неравномерностью развития в результате глобализационных процессов, углублением разрыва между уровнями благосостояния стран, - сказано в “Стратегии национальной безопасности Российской Федерации до 2020 года", - ценности и модели развития стали предметом глобальной конкуренции» [10].

Как отмечает А.Н. Перенджиев, политологов, безусловно, интересуют не только и даже не столько духовные ценности. Как отмечают авторы краткого энциклопедического словаря, ценности в политике - это «значимые стереотипы массового политического сознания, которые позволяют оценивать политическую ситуацию и ориентироваться в ней. В данном словаре зафиксировано, что политические ценности входят как составная часть в целостность социальных ценностей и служат основой осмысления политического опыта страны» [12]. Следовательно, политические ценности являются общезначимыми и при организации противодействия террористической угрозе.

В качестве важнейших российских ценностей в области противодействия терроризму авторы электронного словаря выделили добро, веру, красоту, истину, солидарность, общинность, патриотизм, нравственность, милосердие, сострадание и т. д. [по 8]. В Посланиях Президента РФ Федеральному Собранию нескольких последних лет подчеркивается важная социально-политическая роль таких ценностей, как безопасность, свобода, благосостояние, государственность, законность, человечность, гражданственность, достоинство, патриотизм, нравственность, равенство, справедливость. По мнению автора, именно эта совокупность национальных ценностей должна стать жизненным ориентиром россиян, их современным мировоззрением [5]. При этом отметим, что автор определяет ценностный фактор в антитеррористической политике как влияние системы ценностей, предлагаемых властью обществу на характер развития терроризма. Поэтому разработка и определение ценностей, которые будут способствовать снижению террористической угрозы - одна из ключевых проблем антитеррористической политики современного Российского государства. Но, очень сложно прописать основополагающие общенациональные ценности в законах и законодательных актах. Право по своим свойствам - такой социальный феномен, который вызван потребностью внести в социальную жизнь нормативные начала, организованность и порядок, основанные на началах социальной свободы, активности, ответственности [9]. А.Н. Перенджиев описал различие права и моральных (духовных) ценностей: 
- нормы права устанавливаются государством / моральные ценности формируются в сознании людей;

- нормы права регулируют те отношения, которые нуждаются в правовом регулировании / ценности регулируют поведение, которому можно дать моральную оценку;

- нормы права закреплены в специальных государственных актах / моральные ценности живут в сознании людей;

- право обеспечивается принудительной силой государства / ценность опирается на силу общественного мнения [8].

Из данных различий видно, что в отличие от норм права, ценности, в том числе антитеррористические и антиэкстремистские, могут быть навязаны или предложены обществу не в законодательных актах, а в процессе информационнопсихологического воздействия на граждан со стороны власти.

В России самой социально незащищенной группой населения является молодежь. В силу этого именно представители молодежи являются наиболее активными участниками конфликтов и различного рода деструктивных организаций, в том числе экстремистского и террористического толка. Как отмечает И.В. Абакумова, склонность к экстремизму и терроризму современного молодого поколения России реальна и потому требует пристального внимания и изучения. Современная молодежь стоит перед лицом больших перемен, большой неопределенности и неизвестности, что в свою очередь повышает ее тревогу за свое будущее и рождает у нее желание снять эту тревогу, к сожалению не всегда конструктивными способами [1]. Поэтому на одном из первых мест в государственной политике по противодействию экстремизму и терроризму, на наш взгляд, должен стоять вопрос о работе именно с молодым поколением нашей страны.

П.Н. Ермаков отмечает, что наряду с политическими, социально-экономическими, правовыми, организационными, культурно-образовательными направлениями деятельности субъектов системы по противодействию идеологии терроризма и экстремизма в молодежной среде большое значение имеет информационнопропагандистские направления - «это информационно-аналитическая деятельность (подготовка и выпуск всевозможных памяток, брошюр, книг, обращений, плакатов, социальной рекламы, публикации в прессе о деятельности правоохранительных органов и антитеррористических комиссий, создание тематических документальных фильмов и видеороликов и т.д.); пропагандистская работа; идеологическая деятельность (формирование религиозной и межнациональной терпимости, патриотизма, здорового образа жизни, приоритетов общечеловеческих ценностей и т.д.); организационная деятельность (содействие деятельности общественных и религиозных объединений конструктивной антитеррористической направленности; взаимодействие со СМИ, проведение конкурсов на лучшие материалы антитеррористической направленности, конференций, слётов, «круглых столов» и т.д.); разработка системы социальной рекламы по пропаганде антитеррористических ценностей; создание системы подготовки специалистов в области противодействия идеологии терроризма» [2, с. 72]. 
Среди всех информационно-пропагандистских направлений хотелось бы выделить социальную рекламу как один из мощных инструментов, с помощью которого государство создает не только образ социальной проблемы, но и образ государственного участия в данной области. Характеристика и определение социальной рекламы отражено в статье 3 Федерального Закона «О рекламе» от 13.03.2006 N 38-Ф3 «социальная реклама - информация, распространенная любым способом, в любой форме и с использованием любых средств, адресованнная неопределенному кругу людей и направленная на достижение благотворительных и иных общественно полезных целей, а также обеспечение интересов государства» [11]. Социальная реклама способствует получению важных для общества практических результатов, миссия социальной рекламы - изменение отношения людей к существующим проблемам, а в долгосрочной перспективе - предложение новых социальный ценностей, востребованных обществом. Социальная реклама несет в себе информацию, представленную в сжатой, художественно выраженной форме. Она способна доводить до сознания и внимания людей наиболее важные факты и сведения о существующих в обществе проблемах. Она обращена ко всем и к каждому. Возможности такой рекламы широки, а результаты рекламной деятельности могут быть благотворными. Поэтому социальную рекламу можно использовать как инструмент для формирования антитеррористических и антиэкстремистских ценностей в молодежной среде. Ведь идеология терроризма и экстремизма предполагает воздействие на определенные социальные группы, активное формирование таких групп. С этой целью используются, в том числе, и массовые коммуникации.

А.В. Овруцкий и А.И. Тащёва классифицировали представленные в открытом доступе экстремистские медиатексты на следующие группы.

1. Артикуляция той или иной социальной проблемы как межнациональной, межрасовой, межрелигиозной и требующей радикальных, гуманистически ориентированных, разумных и всем понятных действий (например, предвыборный ролик партии «Родина» «Очистим наш город от мусора»).

2. Оправдание, легитимизация и героизация экстремистских и/или террористических практик (например, ролик на песню Т. Муцураева «Галерея памяти - шахиды в судный день»).

3. Формирование негативных установок относительно той или иной национальной, расовой, религиозной или иной социальной группы (например, ролики на тему трагических событий в Кондопоге).

4. Формирование лояльности к определенным экстремистским действиям (организация материальной и иной помощи экстремистским движениям, формирование потребности в получении дополнительной информации). К такому типу относится, например, реклама, продвигающая экстремистские сайты.

5. Означивание тех или иных социальных событий в рамках экстремистской идеологии. 
6. Формирование групп и повышение их сплоченности (например, реклама по продвижению субкультуры скинхедов).

7. Реклама, напоминающая и активизирующая экстремистские действия (например, реклама, инициирующая людей принять участия в «Русском марше») [6].

Эти же авторы отмечают, что «представленная же в наши дни в Интернет-сети отечественная реклама, направленная на противодействие идеологии экстремизма и терроризма, немногочисленна и, в основном, направлена на формирование толерантности в межнациональных отношениях. В ней практически отсутствуют рекламные обращения, формирующие общую антитеррористическую и антиэкстремистскую идеологию» [6, с. 189]. А ведь именно Интернет является основным источником получения информации и развлечения современной молодежи.

Таким образом, социальную рекламу можно рассматривать как несомненно актуальный и востребованный способ противодействия террористической и экстремистской идеологии в молодежной среде. Сам жанр социальной рекламы более доступен и интересен молодому поколению. Необходимо организовать системную работу по формированию у молодого поколения антитеррористических и антиэкстремистских ценностей.

\section{Литература}

1. Абакумова И.В. Психологические технологии формирования антитеррористических ценностей в молодежной среде // Российский психологический журнал. - 2010. - Т. 7. - № 5-6. - С. 23-26.

2. Ермаков П.Н., Брижак 3.И. Высшее образование и система противодействия идеологии терроризма // Российский психологический журнал. - 2010. - Т. 7. № 5-6. - С. 68-75.

3. Ильин Е.П. Актуальные проблемы противодействия вовлечению молодежи в террористическую деятельность // Материалы научно-практической конференции «Противодействие идеологии экстремизма и терроризма в рамках реализации государственной молодежной политики». Ростов-на-Дону, 12-14 октября 2009 г. - Вып. 2. - М.: «КРЕДО», 2009. - С. 13-22.

4. Манилов В.Л. Национальная безопасность: ценности, интересы, цели // Военная мысль. - 1995. № 6. - С. 40.

5. Национальные ценности, интересы и цели России: сущность и содержание. URL: http://www.plan-konspekt.ru/ogp/ogp111001.htm

6. Овруцкий А.В., Тащёва А.И. Социальная реклама как способ противодействия идеологии терроризма и экстремизма // Материалы научно-практической конференции «Противодействие идеологии экстремизма и терроризма в рамках реализации государственной молодежной политики». Ростов-на-Дону, 12-14 октября 2009 г. - Вып. 1. - М.: «КРЕДО», 2009. - С. 188-190.

7. Перенджиев А.Н. Антитеррористическая политика современного Российского государства: автореф. дисс. ... канд. полит. наук. - М., 2007. - 24 с. 
8. Перенджиев А.Н. Ценностный фактор в антитеррористической политике России до 2020 года: постановка проблемы. - URL: http://www.lawinrussia.ru/

9. Право как ценность. - URL: http://www.e-ng.ru/pravo/pravo_kak_cennost.html

10. Стратегия национальной безопасности Российской федерации до 2020 года. URL: http://www.scrf.gov.ru/documents/99.html

11. Федеральный закон No 38-Ф3 «О рекламе» от 13 марта 2006 года. - URL: http:// www.consultant.ru/popular/advert/

12. Человек и общество: краткий энциклопедический словарь-справочник (политология) / отв.ред. Ю.С. Борцов. - Ростов-на-Дону: Феникс, 1997. - С. 556. 